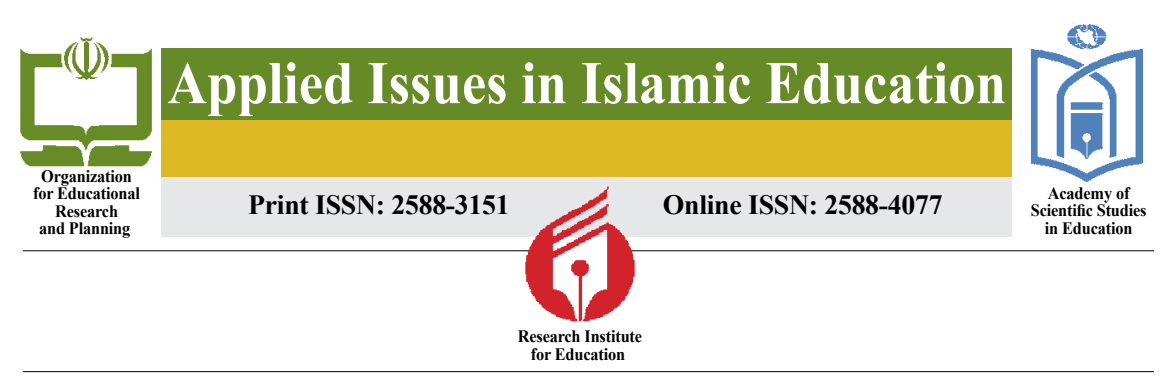

\title{
Identifying and Validating the Characteristics of the Physical Environment of Schools Based on the Islamic Architecture and from the Educational Educators' Perspective
}

- Pari Mashayekh ${ }^{1}$

- Objective: The purpose of this study was to investigate the characteristics of the physical environment of schools in religious education.

- Method: The research method was the mixed exploratory-sequential method. The content analysis method and the survey method were respectively used in the qualitative research method and in the quantitative research method. The statistical population in the qualitative phase of study was consisted of two groups: the first group was the textbooks and papers on Islamic architecture, which were purposefully selected, and the second group was 9 school educational educators who were selected by purposive sampling through the desired items and based on the theoretical saturation rule. The statistical population in the quantitate phase of study included 118 school educational educators participating in the study through the census method. The data collection tools were the interviews and questionnaires that both validity and reliability were confirmed.

- Finding: The findings in the content analysis phase showed that spatial diversity, use of art and visual appeal, attention to the surrounding community (common worship base), design of prayer space (emphasis on the altar and dome), attention to the centrality of the yard, emphasis on natural elements and easy access to facilities (e.g. ablution area) are some of the things that should be considered in Islamic education in designing the physical environment of schools. In the interview phase, the educational educators pointed out the beauty of the prayer place, amenities, flexible and multi-functional design, the focus on the prayer space, being visible and inviting.

- Conclusion: Finally, the findings of confirmatory factor analysis identified five characteristics as a physical environment of schools in religious education: spatial diversity, beauty and visual appeal, attention to the surrounding community, a desirable prayer space, the centrality of the yard, and attention to nature.

Keywords: physical environment, learning space, Islamic architecture, religious education

Citation: Pari Mashayekh. (2021). Identifying and Validating the Characteristics of the Physical Environment of Schools Based on the Islamic Architecture and from the Educational Educators' Perspective. Applied Issues in Islamic Education, 5(4): 127-146.

Received: 2021/01/03 Accepted: $2021 / 02 / 22$

1. An Assistant Professor in Curriculum Planning, the Department of Educational Sciences, Islamic University, Kazeroon Branch, Kazeroon, Iran.

E-mail: Pmashayekh19@gmail.co. (D) 0000-0001-5469-9425

(C) The Authors. 


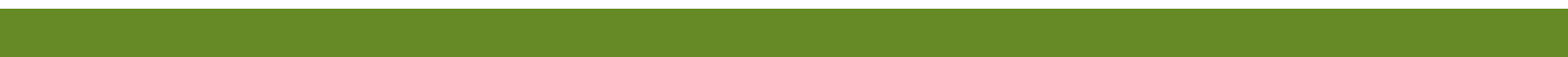



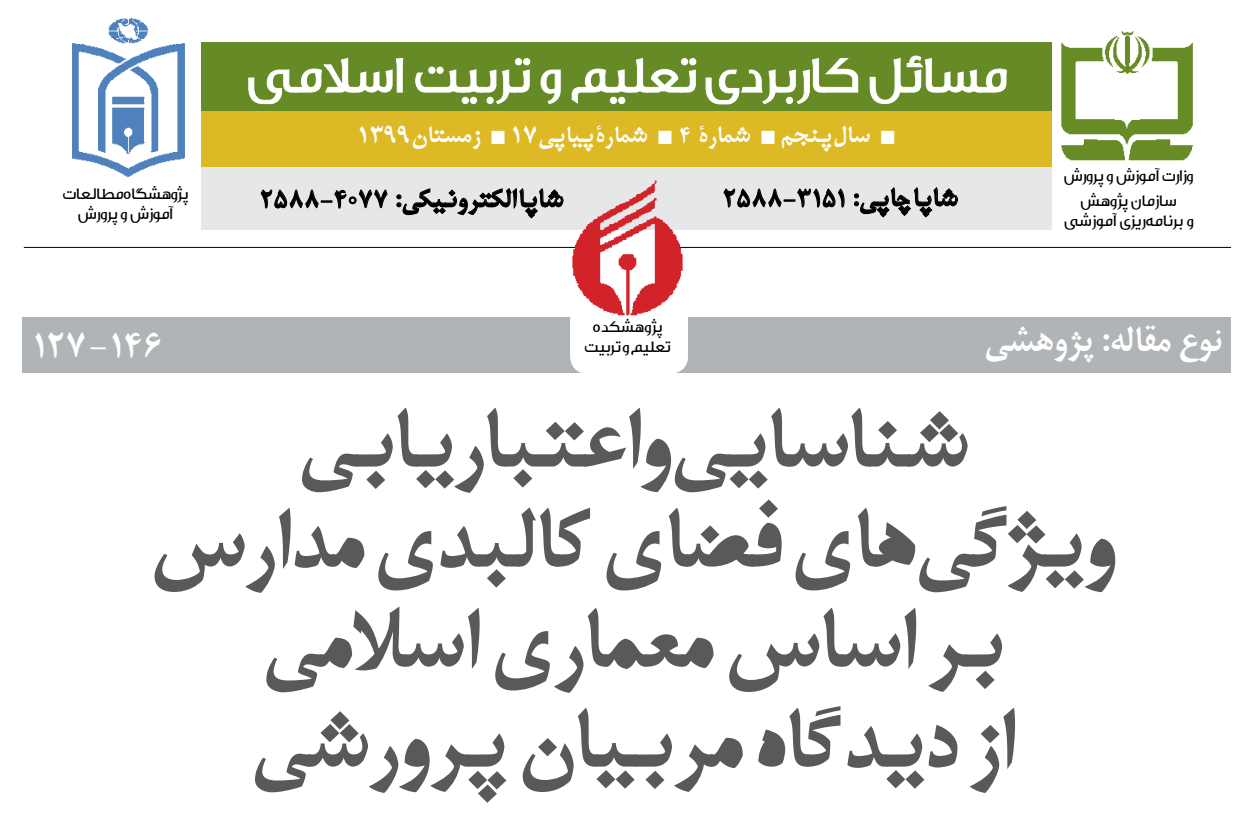

يرى مشايخ

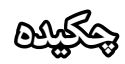

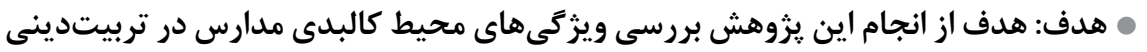

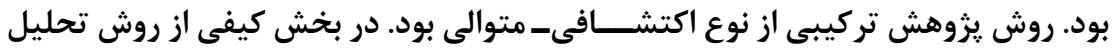

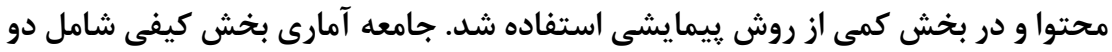

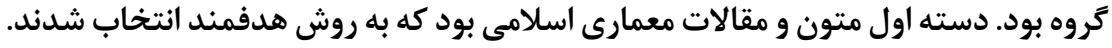

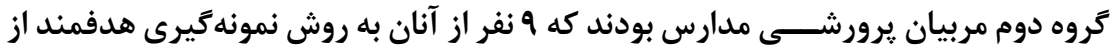

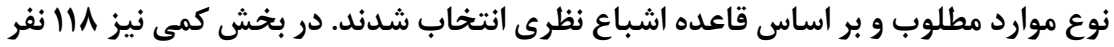

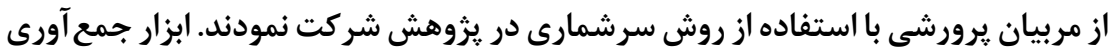

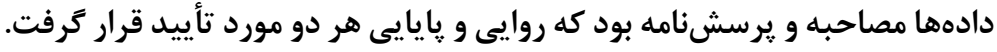

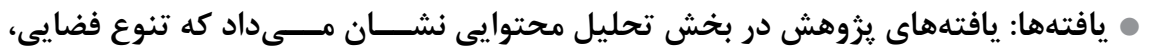

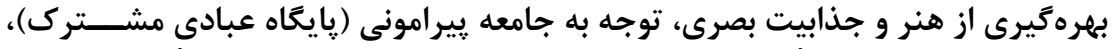

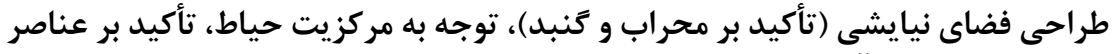

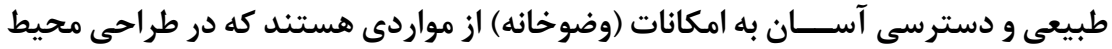

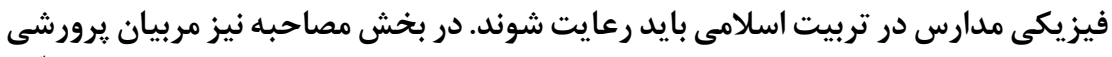

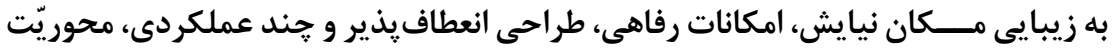

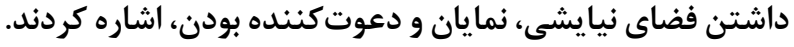

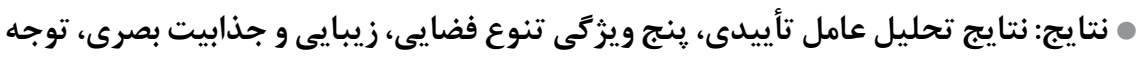

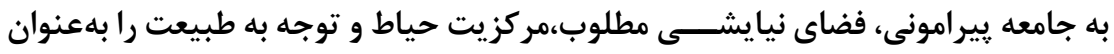

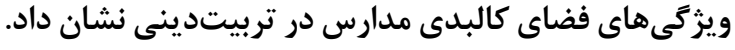

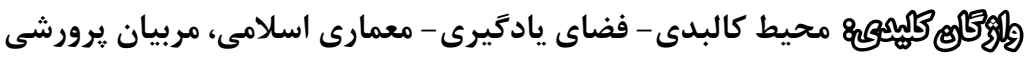




\section{مقفمه}

فضاى كالبدى مدرســه بهعنوان عاملى زنده و يويا در كيفيت فعاليتهاى آموزشى و

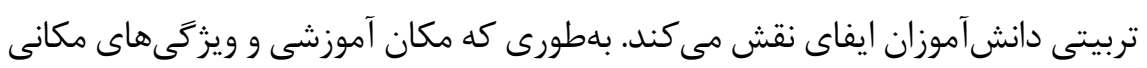

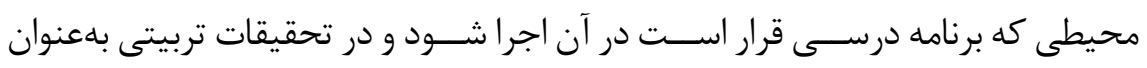

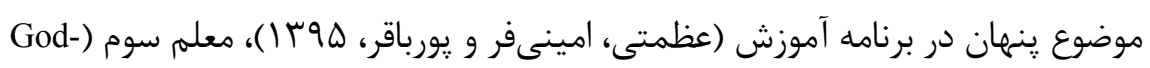

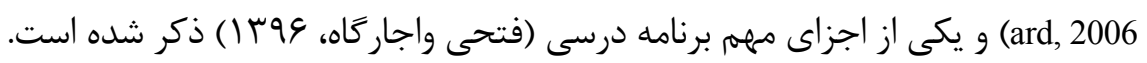

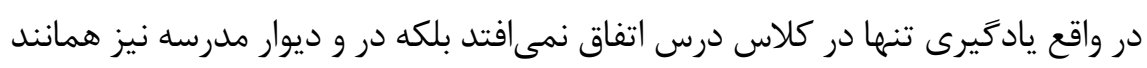

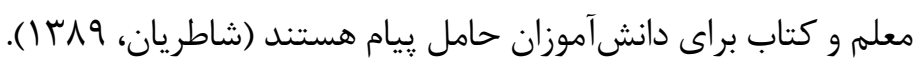

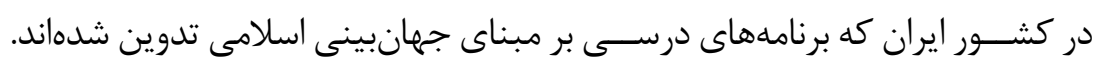

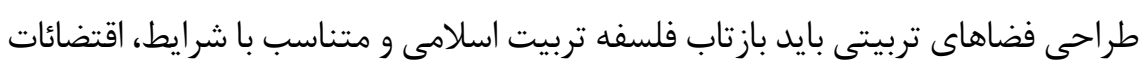

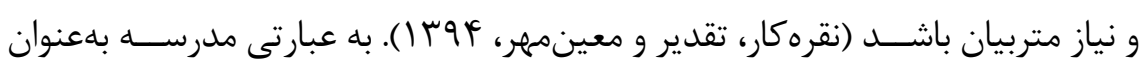
محيط اصلى تربيت و يادگيرى تجلى بخش تحقق مراتبى از حيات طيبه و بهعنوان كانون

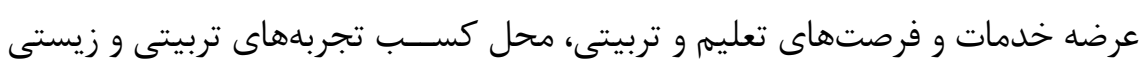

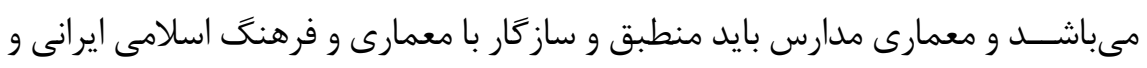
داراى هويت شاخص تربيتى باشد (سند تحوّل بنيادين، هوس (1).

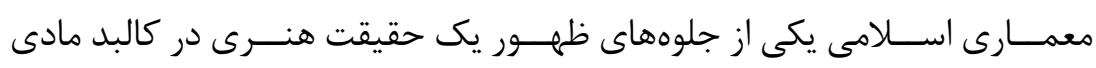

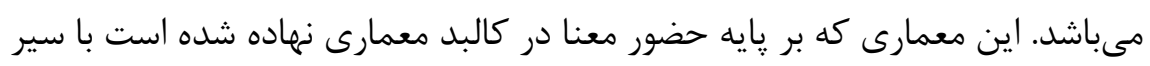

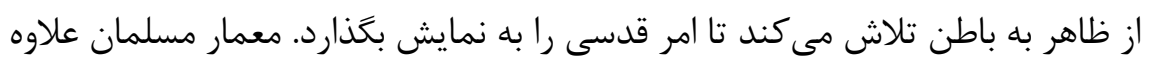

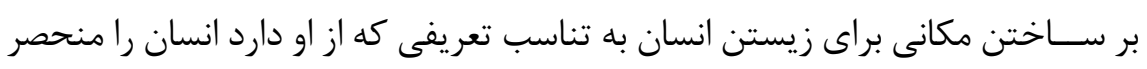

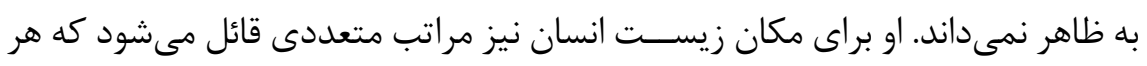

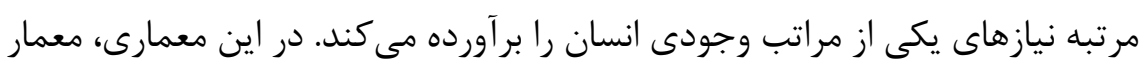

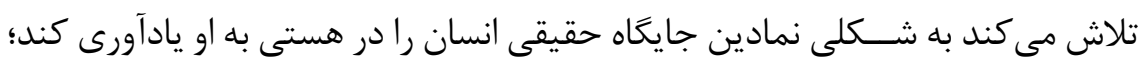

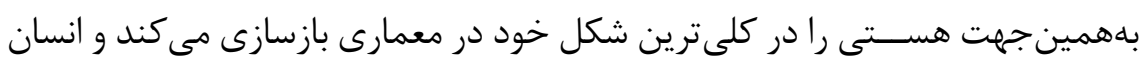

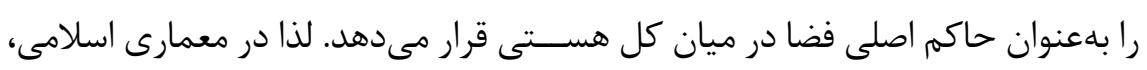

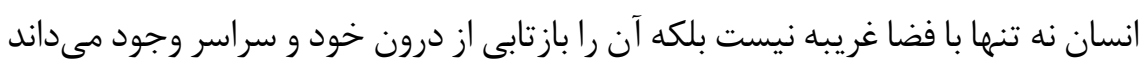

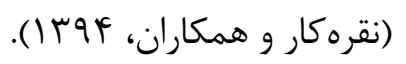

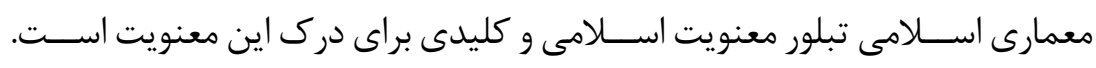


بلهبركت اين معنويت فضاهايى كه در اين معمارى آفريده مىشود، فضايى است كه انسان

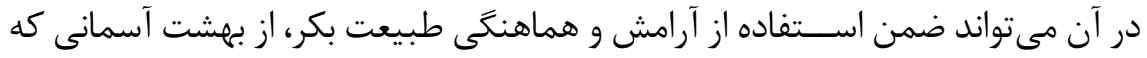

طبيعت بكر تجلى آن است، بهره ببرد. بهشتى كه انسان در عمق وجود خود دارد، جايى اسيى

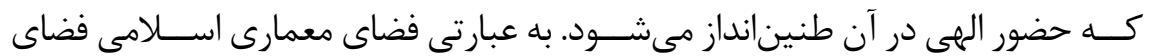
هندســه دكارتى نيست؛ بلكه فضايى كيفى مرتبط با هندسه قدسى است كه به واسطه

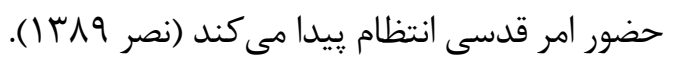

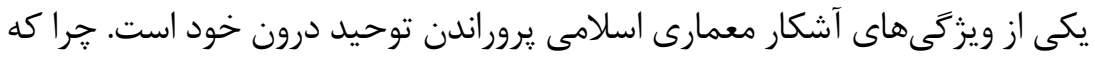

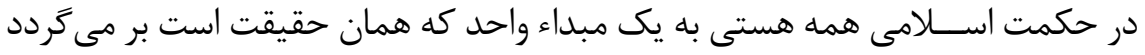

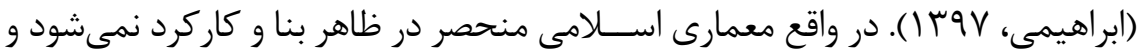

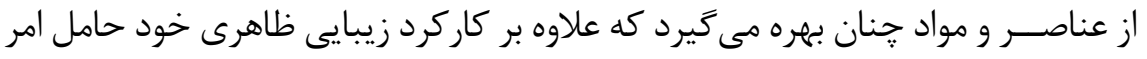

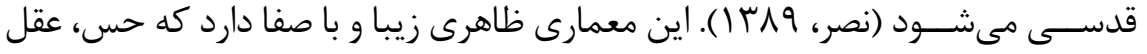

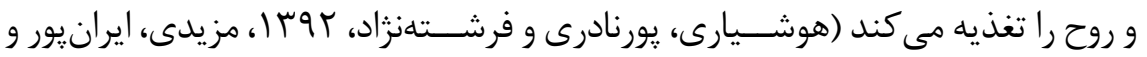

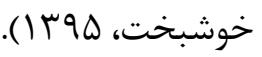

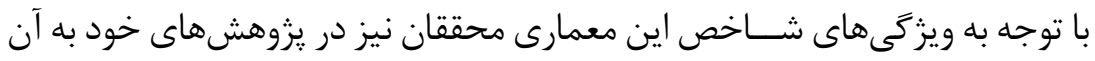

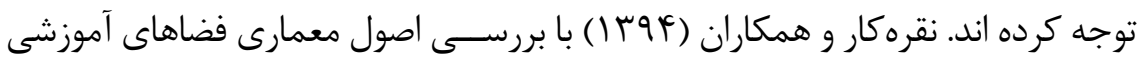

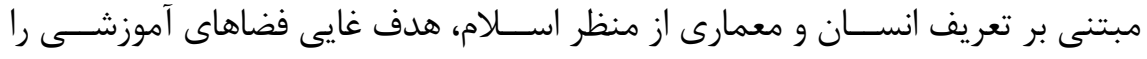

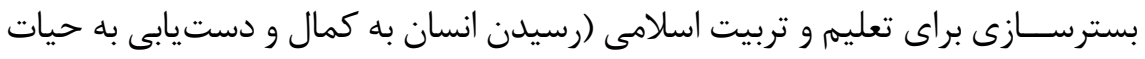
طيبه) مى مانند.

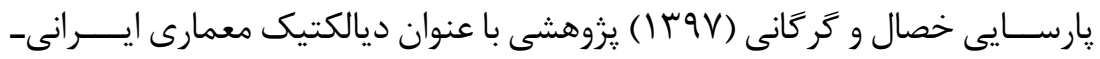

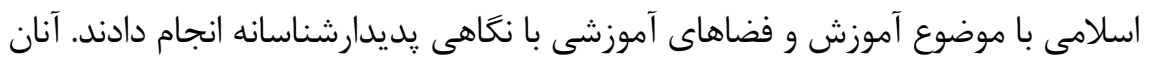

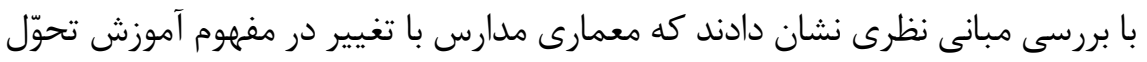

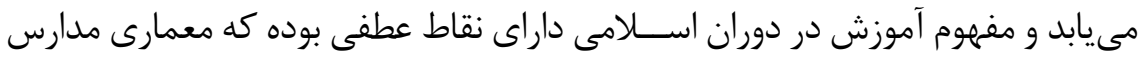
را هم متحول كرده است.

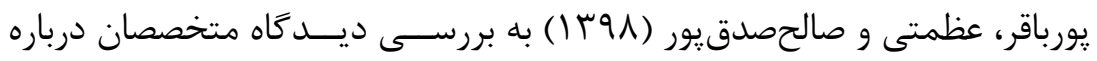
معمارى مدارس ايرانى اسـلامى مبتنى بر كاهش- استرس استفاده كنندكان به مثابه

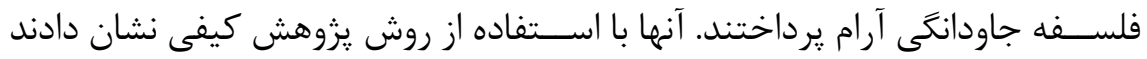

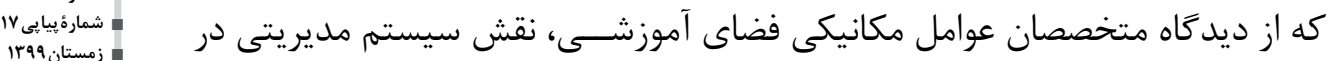


ايجـــاد فضاى رفاهى، تأثير ســـرزندگى در تعاملات بين فــــدى نقش محيط جامعه و همجوارىها در احســاس امنيت و نقش فضاهاى جمعى در ارتباطات كاربران فضاهاى آموزشــى عوامل مؤثر بر كاهش استرس و فلسفه جاودانكى آرامش در معمارى ايرانى اسلامى مىباشد.

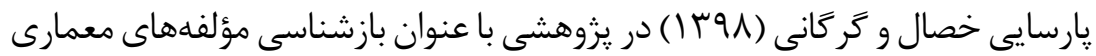
ايرانى_ اسلامى با تأكيد بر فضاهاى آموزشى نشان مى دهند اين معمارى به مواردى جون ســير از كثرت به وحدت، استفاده هدفمند از نور و آب تقدم درونَّرايى بر برون گرايى و مردم وارى اشاره دارد. بهطور كلى اگر خه نظام آموزشى و سند برنامه درسى ملى كشور مابر اساس جهانبينى اسلامى مى باشد اما فقدان راهبردهاى مناسب جهت طراحى معمارى فضاهاى آموزشى

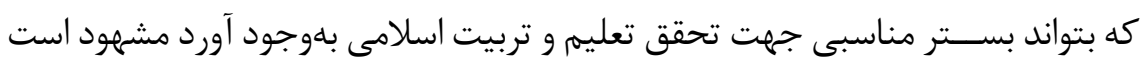
(مخبر دزفولى، سوس|). در همين راســتا در اين يزوهش محقق به شناسايى ويزگى هاى فضاهاى آموزشـى مدارس بر اساس معمارى اسلامى و ديد

$$
\text { سؤالات زير مىيردازد: }
$$

ا. از نظر منابع معمارى اسلامى فضاى كالبدى مدارس جه ويزگ جى هايى دارد؟

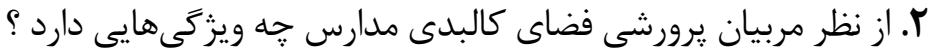

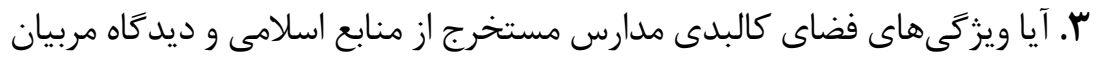

$$
\text { يرورشى اعتبار لازم را دارد؟ }
$$

\section{روش يزوهش}

روش يزوهش تركيبى از نوع اكتشـافىـ متوالى بود. بدينصورت كه ابتدا با استفاده از تحليل محتواى منابع و مقالات مربوط به معمارى اسلامى ويزگگىهاى كالبدى مدارس

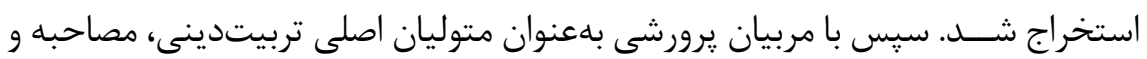
ويزگى هاى موردنظر آنها نيز اســتخراج شد. در مرحله آخر با توجه به يافتههاى مراحل

$$
\text { قبل يرسشنامهاى طراحى و اجرا شد. }
$$

جامعه تحقيق در بخش تحليل محتوا شامل همه متون و تحقيقات بيشين در زمينه معمارى اسلامى بود كه به روش نمونه گيرى هدفمند از نوع موارد مطلوب انتخاب شدند. 
بدينصورت كه مقالات و منابعى كه بيشترين اطلاعات را در زمينهُ مورد بررسى در اختيار محقق قرار مى دادند مورد تحليل قرار گرفتند.

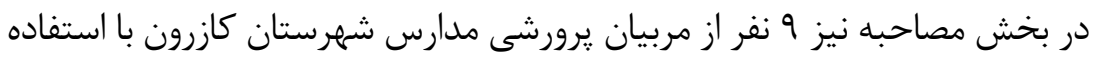

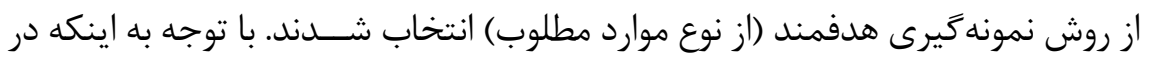
تحقيقات كيفى رسيدن به اشباع نظرى ملاك تعيين حجم نمونه است، بعد از مصاحبه

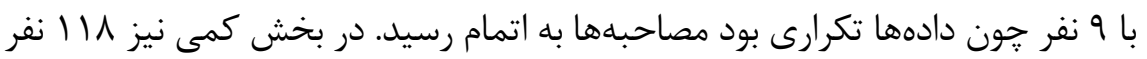

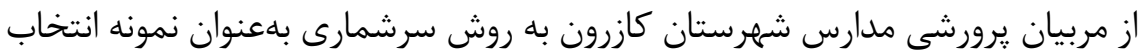

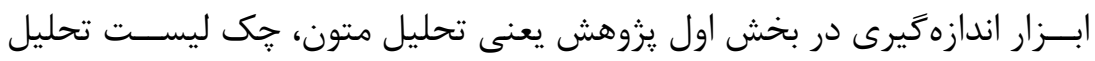

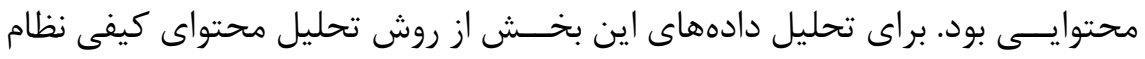

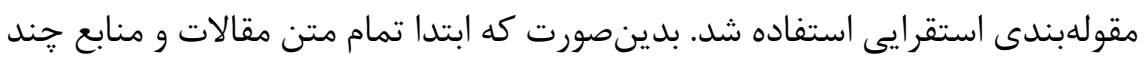

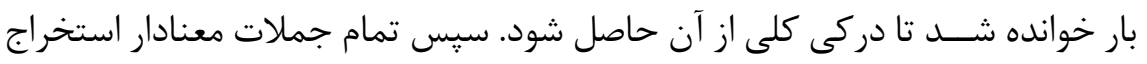

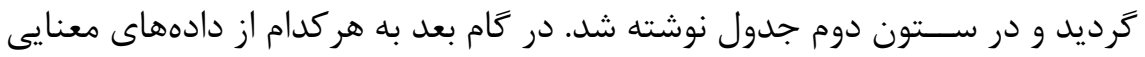

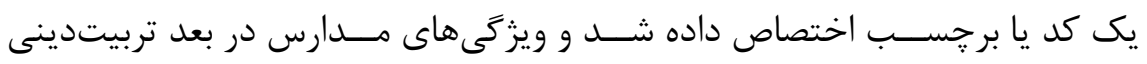

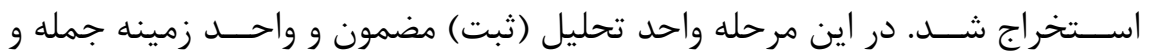

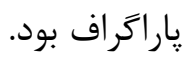

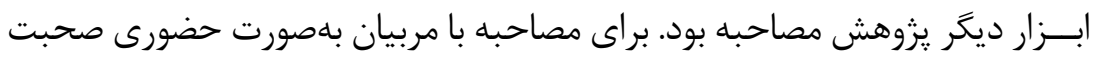

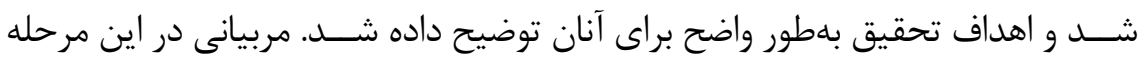

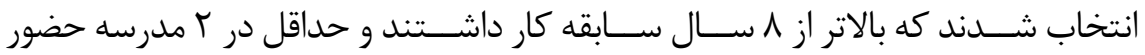

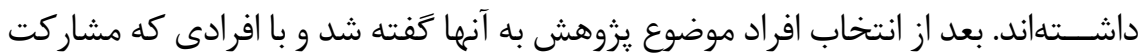

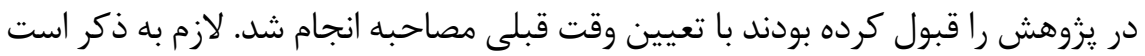

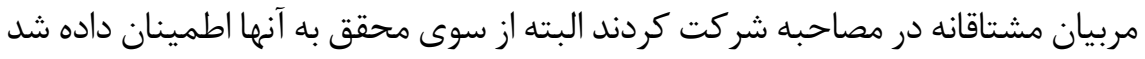

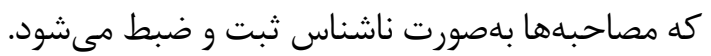

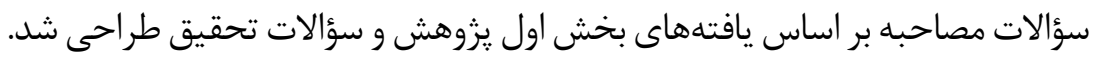

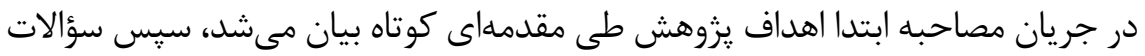

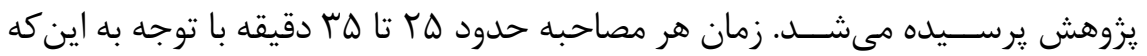


بـــراى تعييــن روايى مصاحبهها از روشهاى مختلفى كه يِيشـــنهاد شـــده اســت

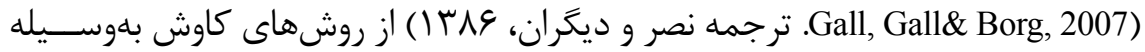
افر اد موردمطالعه استفاده شد. بدينمنظور متن يياده شده مصاحبهها، به آنها باز گردانده شد و از مشاركت كنندكان تقاضا شد، يافتههاى كلى را ارزيابى كرده و در مورد صحت آن نظر دهند و خواسته شد تا هر گونه اصلاح يا نظر جديدى دارند اعلام كنند.

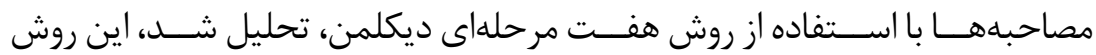
دســت يابى بـــه درك عميق تـــــ از تجربيات زنـــده در فرايند تفســير را فراهم مى كند (Diekelmann, Allen \& Tanner,1989) كاغذ نوشته و بهدقت مطالعه شد و مرحلهُ دوم، متن هر مصاحبه توسط يروهشگر بررسى

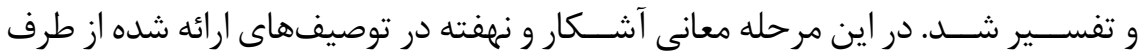
مشاركت كنند مرحلهُ جهارم، تناقض هاى موجود در تفسيرهاى ارائهشده از طرف گروه يزوهش، مشخص و رفع گرديد. ســـيس در مرحلهُ ينجمه، با استفاده از روش مقايسه و مقابله متون، نسبت به تعيين و توصيف درونمايهها اقدام گرديد. در مرحلئ ششم، يافتههاى مطالعه در قالب درونمايههاى استخراجشده فوق، توسط اعضاى گروه تحقيق بررسى شد. در مرحلة هفتم نيز، طرح نهايى يافتهها در قالب درونمايههاى اصلى مشخص گرديد. ابزار ســـوم يزوهش يرســش نـامه بود. بر اســاس يافتههاى تحليل محتوا و مصاحبه يرســشنامهاى • آسؤالى، بر اساس مؤلفههاى اســتخراج شده در مرحله كيفى (تحليل محتواى منابع اســلامى و مصاحبهها) در ه بعد تنوع فضايى (أ)، زيبايى و جذابيت(ه)،

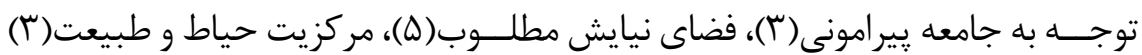
تهيه شد. نمرهدهى يرسشنامه بر اساس طيف ليكرت ه درجهاى از كاملاً موافقم تا كاملاً مخالفم بود. روايى يرسشنامه ازطريق اعتبار محتوا بررسى شد. بدينمنظور ابتدا يرسشنامه در اختيــار ه نفر از متخصصان تعليم و تربيت و دونفــــــ از متخصصان معمارى قرار زرفت.

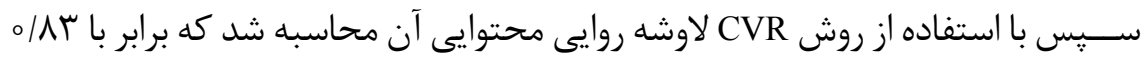
و قابلقبول بود. يايايى يرسشنامه نيز با استفاده از ضريب آلفاى كرونباخ (1/9/ه ) تأييد 


\section{يافنهها}

بررسى اولين سؤال تحقيق \از نظر منابع معمارى اسلامى فضاى كالبدى مدارس خه

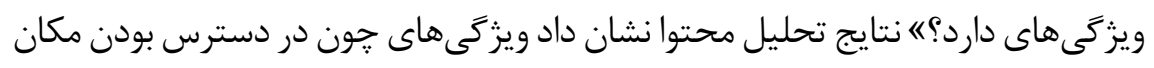

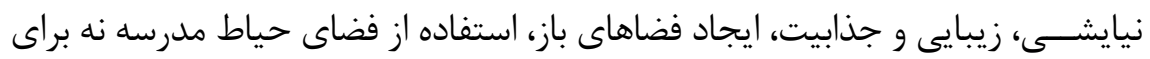

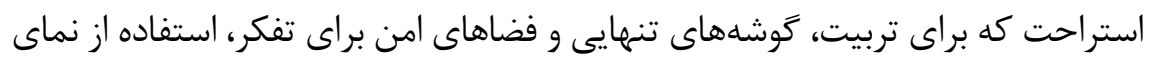

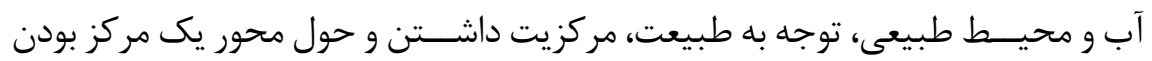
اهميت زيادى دارد (جدول شماره (1).

جدول ا. مؤلفههاى استخراج شده از تحليل محتواى منابع معمارى اسلامى

\begin{tabular}{|c|c|c|}
\hline منبع & مقوله & مؤلفه \\
\hline 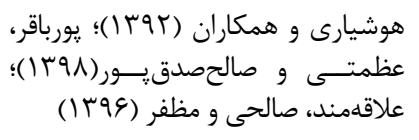 & فضا داشتن كَنبد و محرد وجود داشتن & طراحى فضاى نيايشى \\
\hline 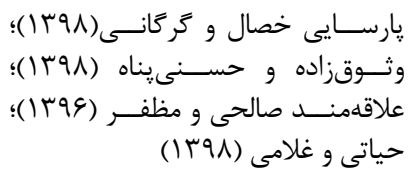 & سرختان & مركزيت حياط \\
\hline 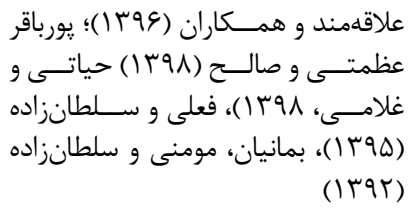 & 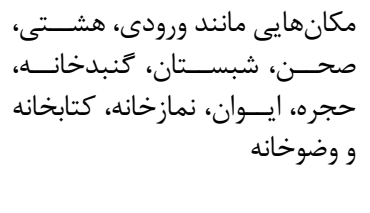 & تنوع فضايى \\
\hline 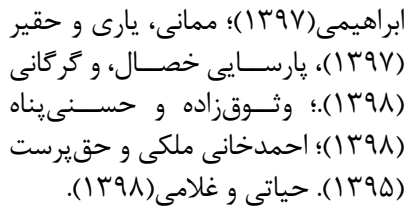 & 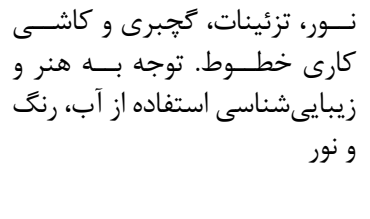 & زيباسازى \\
\hline 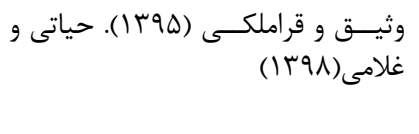 & 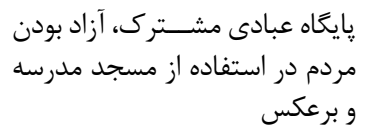 & توجه به جامعه يِرامونى \\
\hline 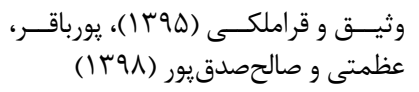 & بهداشتى وضانــه، امكانــات ســرويس & امكانات بهداشتى در \\
\hline
\end{tabular}




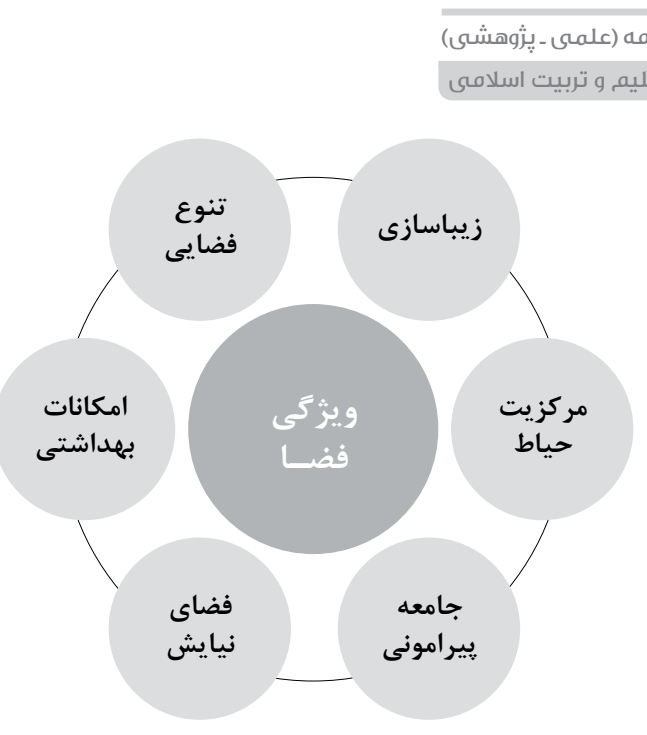

\section{شكل ا. يافتههاى مستخرج از تحليل متون}

\section{تنوع فضايـى (با تأكيد بر فضاهاى دينى): در مدارس اســلامى مكانهاى}

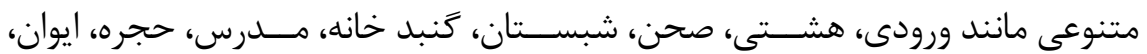

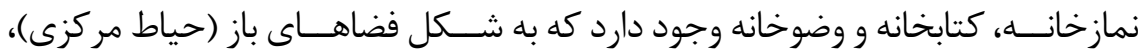

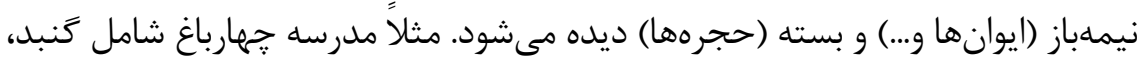

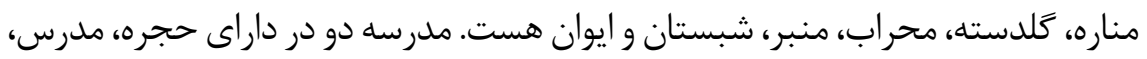

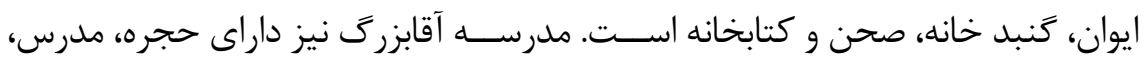

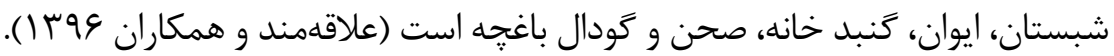

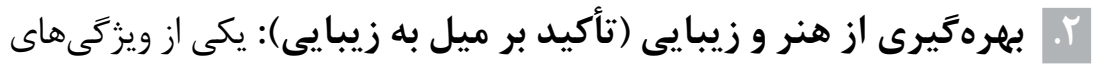

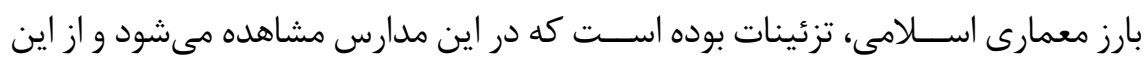

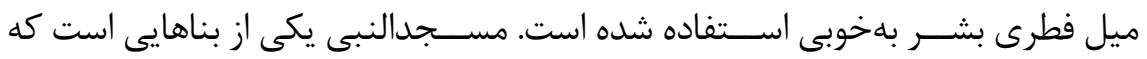

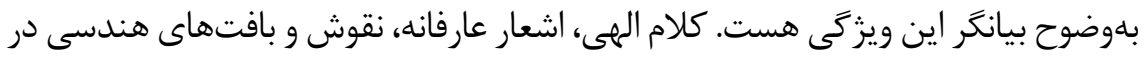

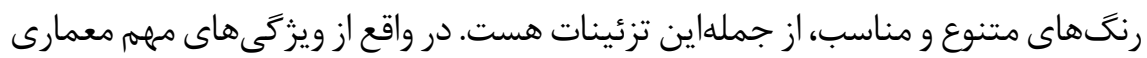

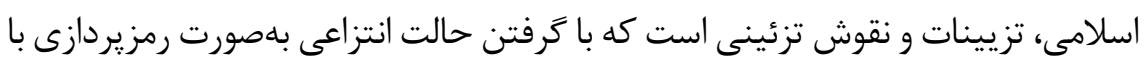

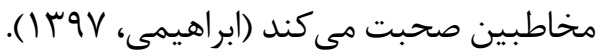

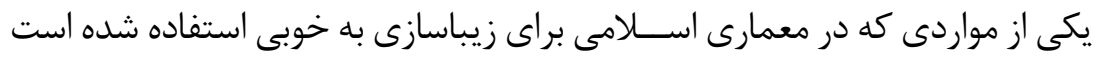

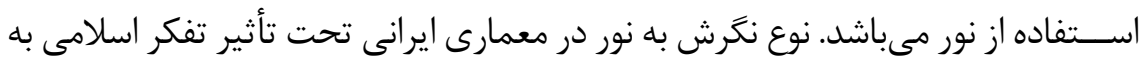

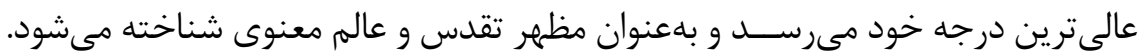


در واقع نور بلعنوان غيرمادىترين عنصر محسوس طبيعت، همواره در معمارى اسلامى

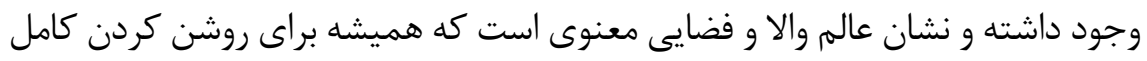

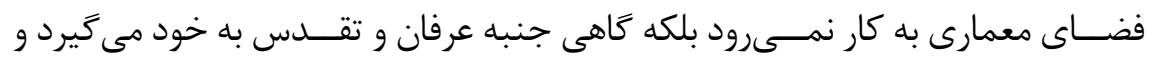

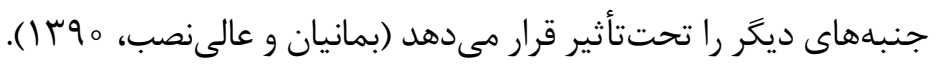

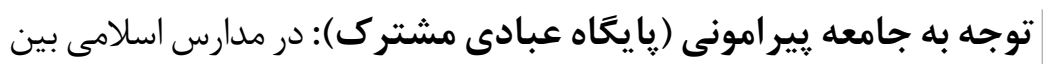

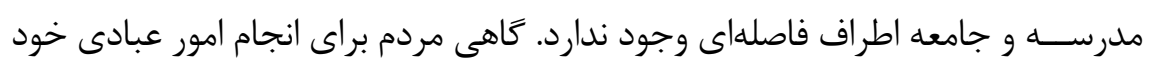

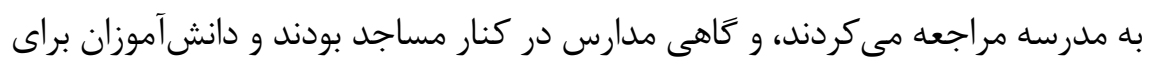

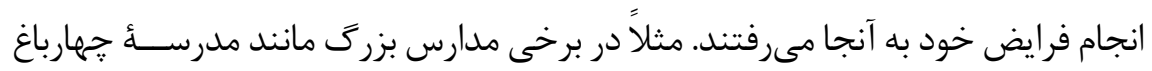

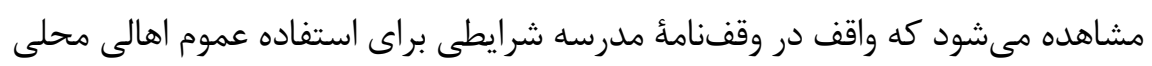

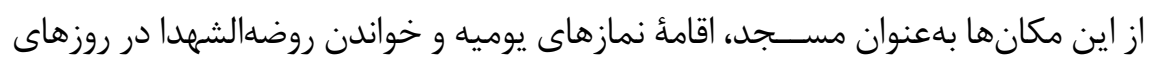

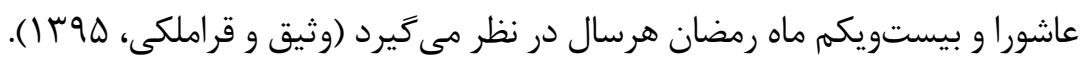

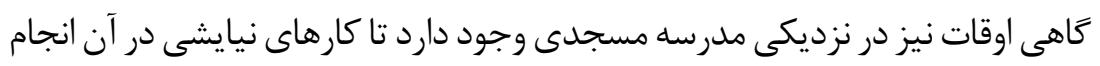

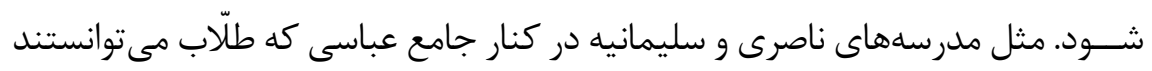

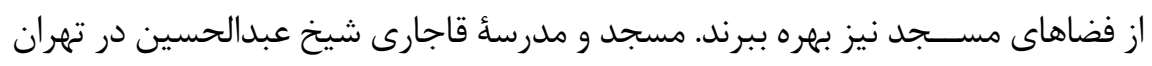

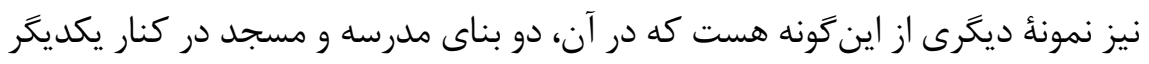
قرار

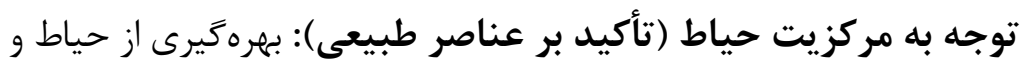

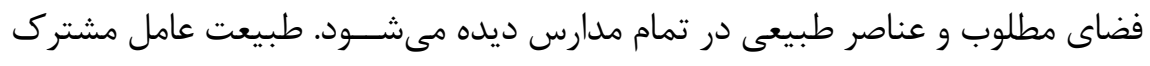

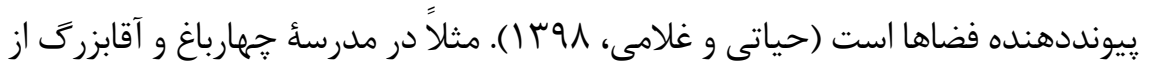

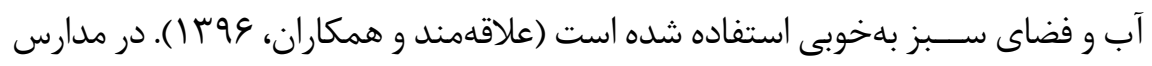

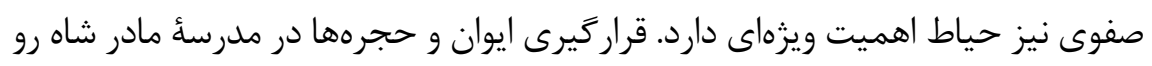

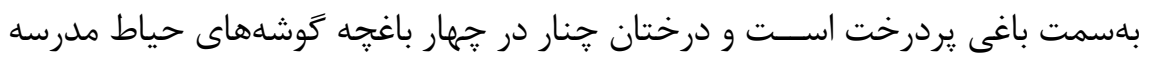

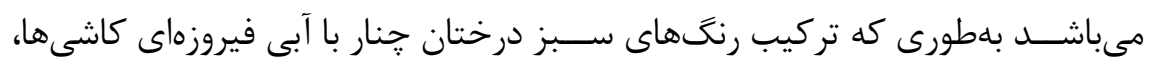
فضايى مناسـب آموزش را بهوجود آورده بود؛ در كوشه و كنار حياط، روى سكو سكوها، ايوان

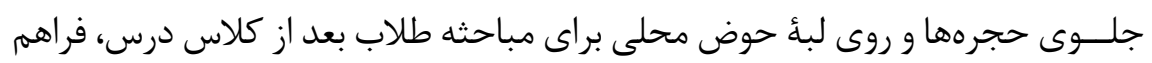

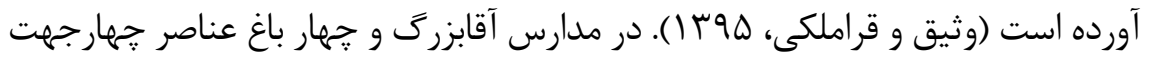


يكى ديگر از موارد مورد توجه در معمارى اسـلامى حضور آب است. آب در معمارى اسلامى در حوضهايى با فرمها و قالببندىهاى مختلف در حياط ساختمان حضور دارد. آب علاوه بر تعبيه يك فضاى دلنشين با زيبايى بصرى از نقش خنك كنندگى برخوردار است. زيرا آب با خاصيت روان و زلال خود و با صداى ملايم، طراوتى وصفنشدنى به روح مخاطب مىبخشد (وثوقزاده و حسنى يناه، 19 1) ).

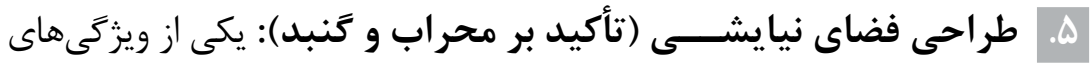
بارز در مدارس اســلامى وجود فضاى نيايشى به شـــل مسجد (مدرسأه خان در شيراز،

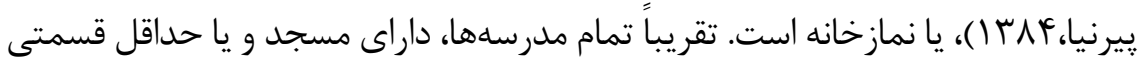
بهعنوان فضاى نيايشــى بودهاند. به عبارتى در دورة سلجوقى، مسجد از عناصر مرهم هر مدرسه محسوب مىشد و فضاى نيايشى در انتهاى ايوان قبله، بهصورت ايوان و يا گنبد خانه ديده مىشود (وثيق و قراملكى، هوس ا ). مدارس ايلخانى داراى فضاى نيايشى برجستهاى بودهاند. اين فضابا كنبد خانة محرابدار، به گونهاى تلفيق مسجد با مدرسه را نشان مى دهد. بيشتر مدارس صفوى نيز مانند مدرسه ملاعبدالله در اصفهان، داراى فضاى نيايشــى مىباشند كه گاهى بهصورت شبستان ديده مىشود. در برخى از مدارس صفوى كه فقط رويكرد آموزشى داشتهاند، در ايوانها محرابى را ايجاد مى كردند و از ايوان بهعنوان نمازخانه بهره مىبردند (هوشيارى و همكاران، بوس ا ).

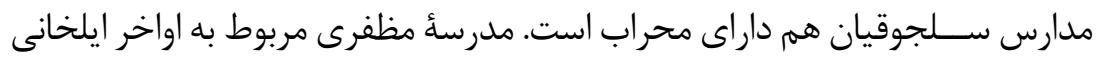

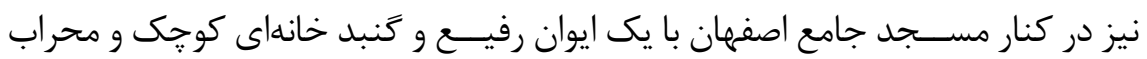

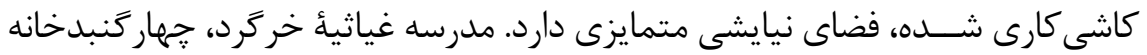
در جههار كنج بنا دارد كه دو گنبد خانه دو ســوى ايوان ورودى بزرگتر است. يكى از اين دو گنبد خانه داراى كاركرد نيايشــى است و بهَّونهاى جداسازى ميان فضاى نيايشى و آموزشى در اين مدرسه ديده مىشود (علاقهمند و همكاران، و وبا ).

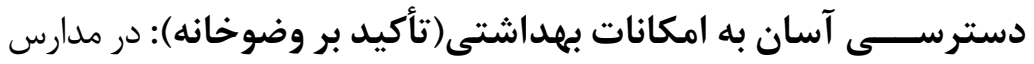
اسلامى فضاى بهداشتى و وضوخانه نزديك نمازخانه ساخته مىشد تا افرادى كه از بيرون براى اقامه نمــاز مى آيند؛ ناجار از رفتن به درون صحن و ايجاد مزاحمت در زندكى آرام طلاب نباشند. در مدرسه جهارباغ بهدليل وجود ورودى مجزا، دسترسى آسان به نمازخانه براى عموم ممكن مىشد (وثيق و قراملكى، هوس (I) 


\section{بافثنه داى مصاحبه}

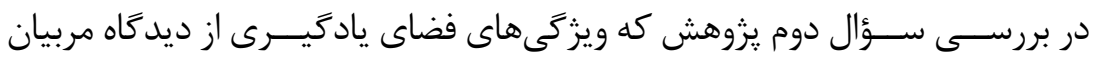

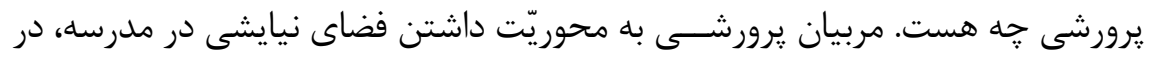

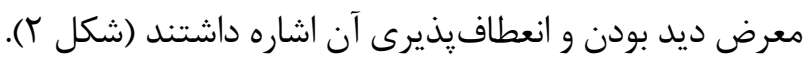

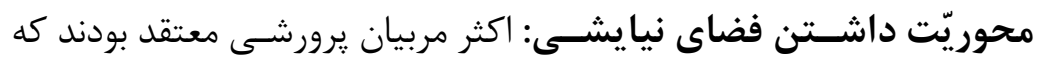

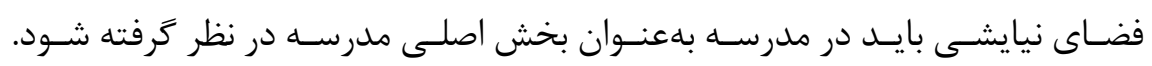

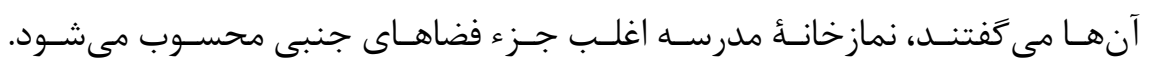

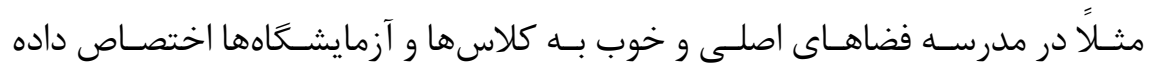

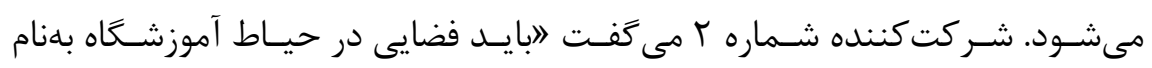

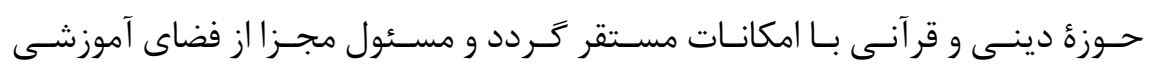
داشـته باشد. «وزة دينّ

در معرض ديد بودن و دعوت كننده بودن: مربيان معتقد بودند كه فضاى

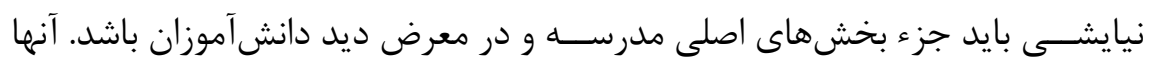

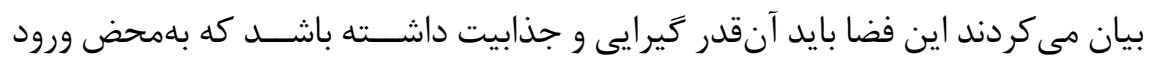

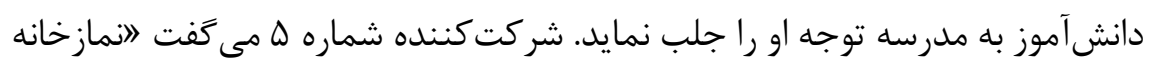

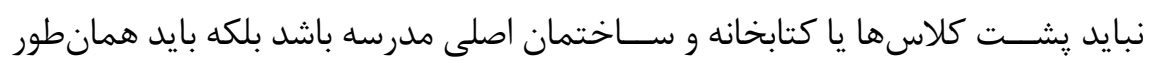

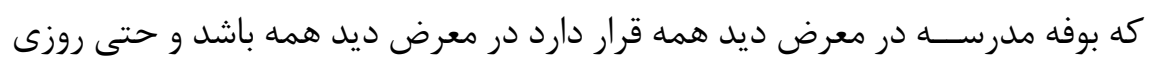

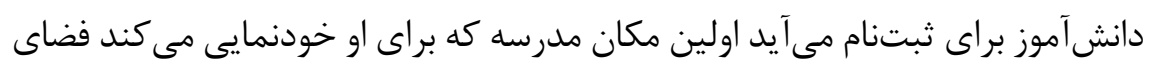

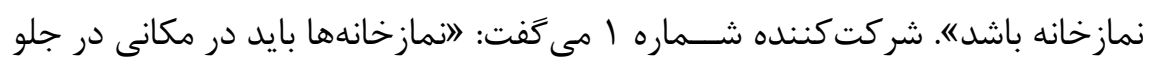

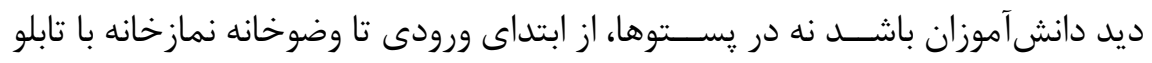
نمايش داده شود.

طراحى انعطاف يذير و جند عملكردى فضا: برخى از مربيان برورشى معتقد

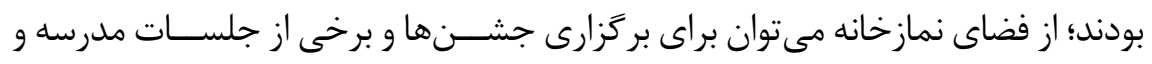

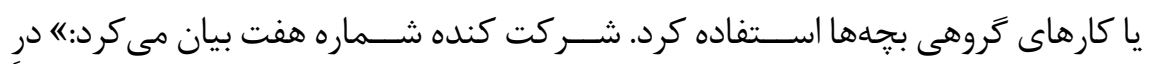

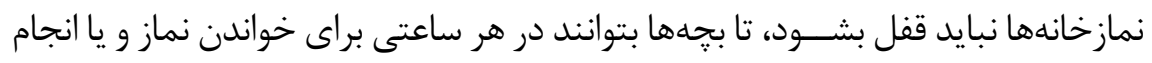

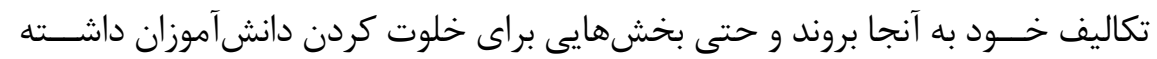


جذابيت و زيبايى: يكى از بيشــترين مواردى كه مربيان بر آن تأكيد داشتند زيبايى و جذابيت فضاى نمازخانه بود. آنها معتقد بودند كه فضاى نيايشى مدرسه بايد وسيع، بزرگ، نورگير باشد، از عكس و تصاوير زيبا و شاد بر روى ديوار نمازخانه استفاده شود، جملات زيبا و آموزنده از بزركان و همجنين احاديثى از امامان معصوم بر روى ديوار

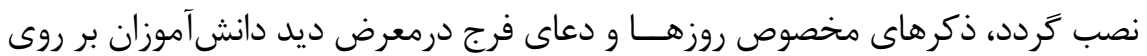
ديوار نمازخانه قرار داده شود. شركت كننده شماره V مى گفت: الفضا بايد دلباز و بزرگ باشد، تنَ و تاريك نباشد

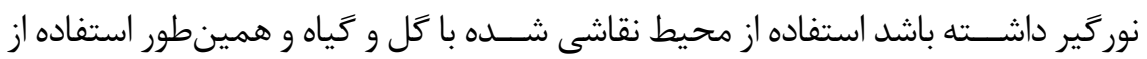
نقاشىهاى شــاد در محيط نمازخانه مى تواند كمك كند." وى همجنين به "ريختن گل

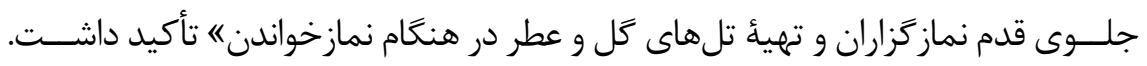
شـــركت كنـنده شماره ه بيان مى كرد: الردر ورودى نمازخانهها با هلال هاى نوشتهشده از اسماء مقدس تزئين گردد و در صورت امكان جلو نمازخانه و وضوخانه باغجهاى ازگل ساخته شود در نمازخانه كتابخانهاى راهاندازى شود كه بيشتر قصههاى مذهبى در آن موجود باشده.

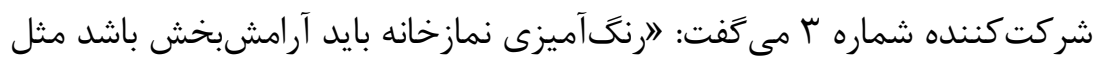
رنت آبى يا ســـز ملايم استفاده شود". وى همجنين مى گفت فومهاى ديوارى برجسته عروســكى با موضوع وضو تهيه شــود و روى ديوار وضوخانه نصب كردد. شركت كننده شماره r مى كفت اوضوخانه از نظر بهلداشتى تميز و دعاى وضو و جند تا شعار روبه روى موض وضوخانه نوشته شــود. نمازخانه هم با فرشهاى جذاب فرش شود، ديوارهاى نمازخانه

$$
\text { تزيين شود و دعاها و تعقيبات نمازها نصب گردند." }
$$

ه. امكانات رفاهى: يكى از موارد ديخرى كه مربيان به آن اشــاره داشتند وجود امكانات رفاهى در نمازخانه مدرسه بود. آنها معتقد بودند كه مدرسه بايد داراى نمازخانه مجهز باشد. مربيان يرورشى حتى تعبيه مكانى جهت پاشويه و تعويض جوراب را ييشنهاد

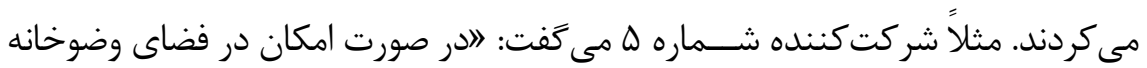
علاوه بر لوله كشــى آب، حوضجهاى ســاخته شوده. شـــركت كنـنده شماره r مى كفت: "إجادرنمازهايى با گل هاى متنوع تهيه شود؛ مكانات سرمايشى و گرمايشى نمازخانه در مدارس زير صفر اســت كه حتماً لازم است تجديدنظر شود. در وضوخانه از شير حسى مَّر 


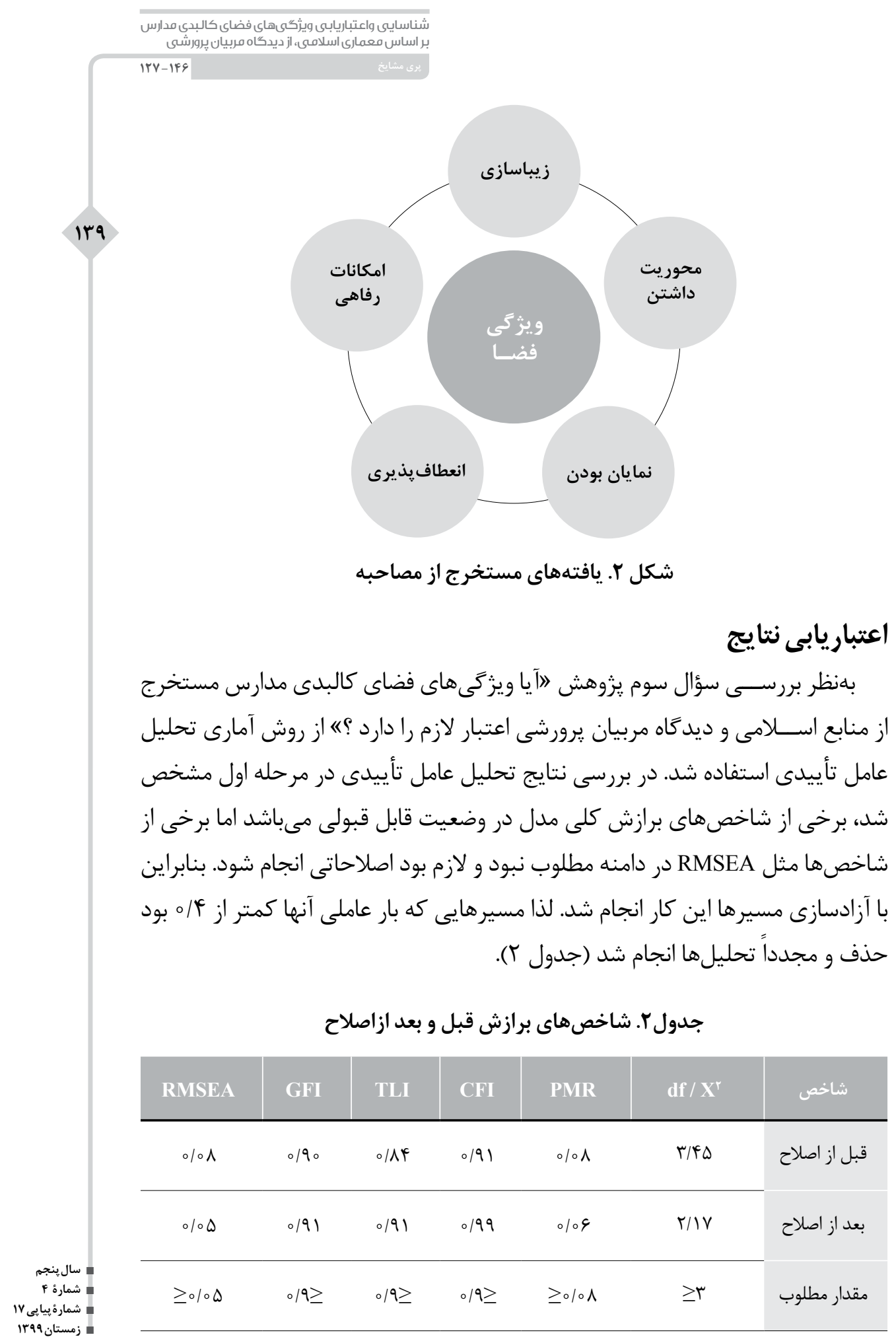


همانطور كه در جدول شــماره r مشاهده همه شاخصها در وضعيت قابل قبول و

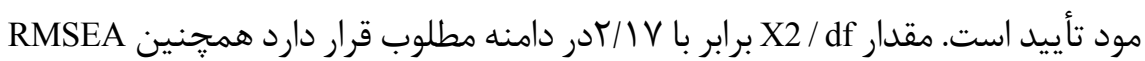
PNFI، NNFI، نيز برابر با ه ه / و در دامنه مطلوب هست. همجنين شاخص هاى ديخر مثل همخَـى در دامنه مطلوب قرار گرفتند. CFI نيــز برابر با 91/هFI، IFI مىباشد.در بررسى معنادارى بارهاى عاملى نيز همان طور كه در شكل س مشاهده مىشود بارعاملى همه بالاتر از \&/ه و معنادار مىباشد.

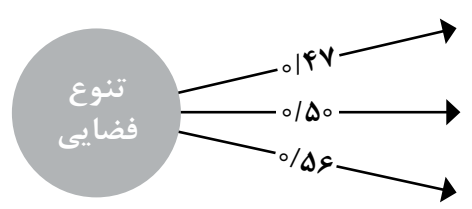
وجود مكانهاى متنوع مانند ورودى، هشتى و غيره وجود فضاهاى باز، نيمهباز و بسته كوشههاى دنج و فضاهاى امن براى تفكر و سكوت

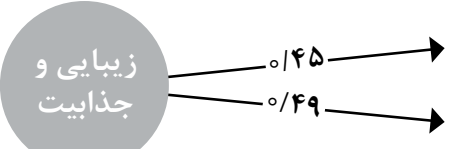
استفاده از عكس و تصاوير استفاده از رنتى ونور مناسب

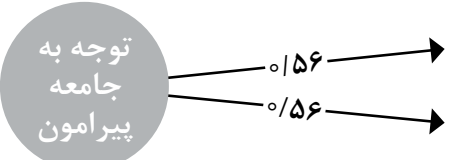

بر گزارى برخى از مراسمات مدرسه در مسجد محله جزء فضاى اصلى مدرسه و آزادى حضور مردم

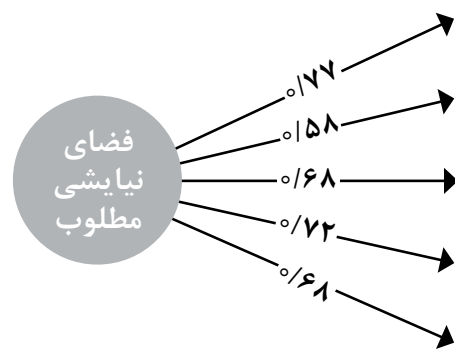
وجود مسحد در مدرسه و آزادى حضور مردم داشتن محراب و كنبد طراحى انعطاف يذير و جندعملكردى نمايان و دعوت كننده بودن داشتن امكانات رفهى و بهداشتى مناسب

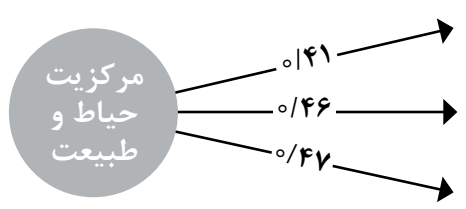
وجود حوضهاى كوجك و فوارههاى آب در ...

مركزيت حياط و حسترش عناصر مدرسه يِيرامون آن داشتن درخت و سرسبزى

شكل r. ويزگى هاى محيط كالبدى مدارس و بار عاملى آنها 


\section{بحث و نتيجه كَيرى}

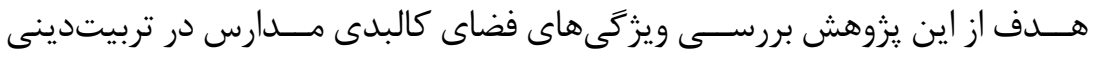

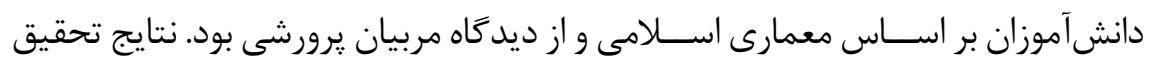

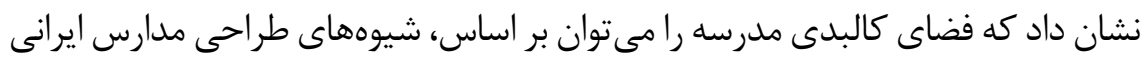

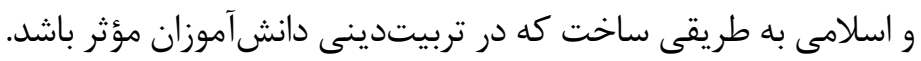

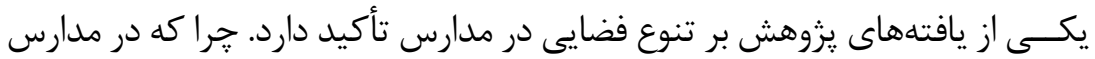

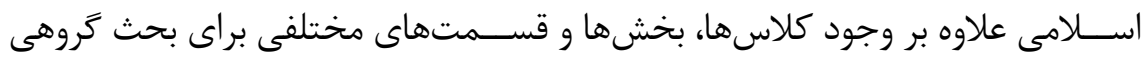

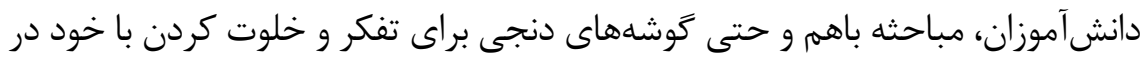

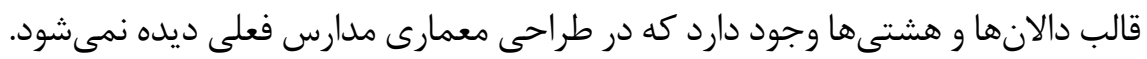

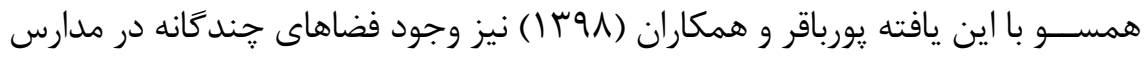
اسلامى را نشان مى دهند. يافته مههم ديكر مركزيت حياط و استفاده از عناصر طبيعى در حياط مىباشد. درواقع دمان

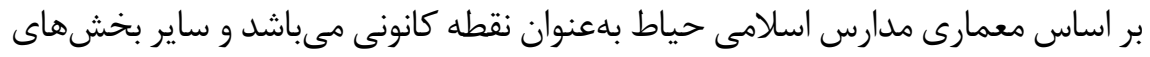

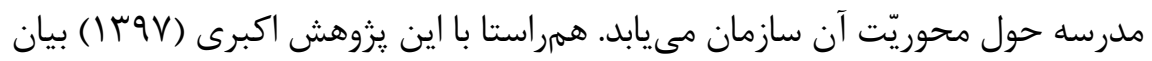

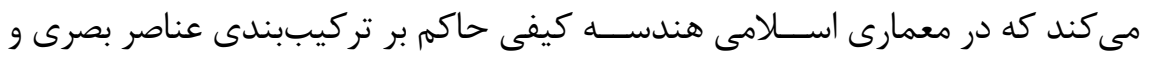

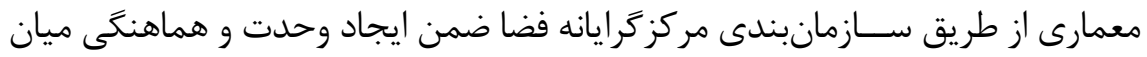

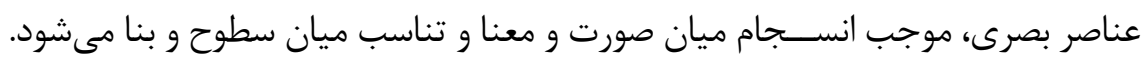

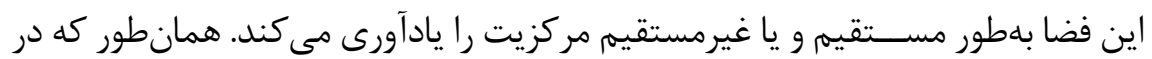

$$
\text { معمارى كعبه اين مركزيت ديده مى شود. }
$$

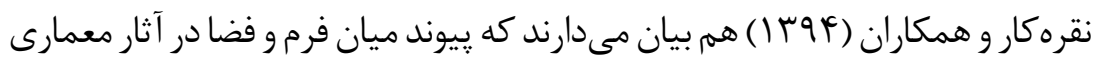

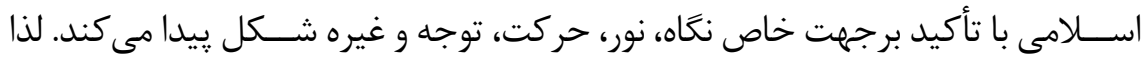

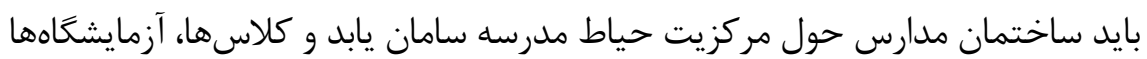

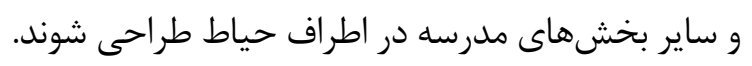

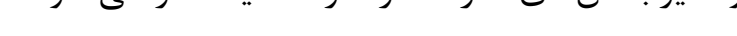

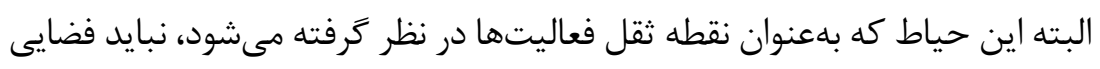

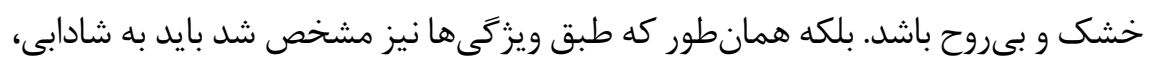

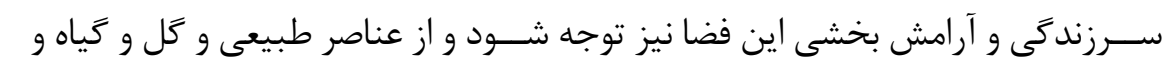

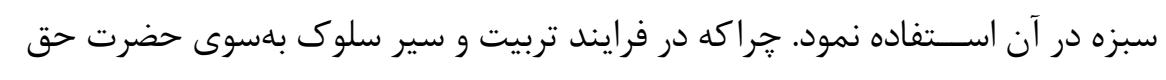


نيز يكى از توصيههاى اوليا و مربيان الهى، آشنايى و انس با طبيعت (سير آفاقى) و تأكيد بر طبيعى زيستن است. درواقع تمركز بر روى طبيعت يكى از مهممترين نيازهاى مدارس ايجاد شـــده است. حضور آن باعث افزايش روابط عاطفى ميان انسانها مىشود. تماس با طبيعت نقش اصلى در رشد كودى و سلامت روان او دارد (طباطبائيان، عباسعلىزاده و

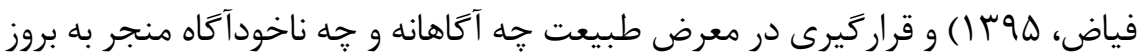
واكنش هاى مثبتى از سوى فرد مىشود (Hinds \&Sparks, 2011). همسو با اين يافته مير مرادى (هوس () نيز استفاده از ديد بصرى به فضاى سبز طبيعى از فضاهاى داخلى، اســـفاده از شيوههاى باغســازى ايرانى در طراحى محوطهها، ايجاد تنوع فضايى با ايجاد فضاهاى متنوع بســته، باز و نيمهباز را از راهكارهاى طبيعتمحور فضاهاى آموزشــى براى تحقق اهداف برنامه درســى ملى مى داند. كاتب، ديواندارى و دانايى (هوس (ا) هم بيان مىدارند دانش آموزان ترجيح مى دهند تا با محيط عجين شده و اجازه دخالت و درك آن را داشته باشند. به عبارتى ارتباط بصرى با محيط طبيعى يكى از ضرورىترين موارد در طراحى مدارس محسوب مىشود.

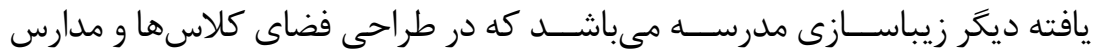
مى تـــوان از تابلوها، ابزارهاى تزئينى و جشـــمنواز، نقش هاى اســليمى و آيينه كارىها و كاشى كارىهاى زيبا استفاده نمود. در روايتى امام صادق مىفرمايند: خد/وند زيباست و زيبايى را دوست دارد و مؤمن بايد خانه /ش را سفيد كند و آستانههاى خانه را از خاكروبه بيبيرايد (حرعاملى، س|f|| ق، ج ه: 9). در ســوره نمل نيز از زيبايى كاخ سليمان و اينكه حياط قصر از بلور صاف بوده است به زيباسازى فضا اشاره مى كند.

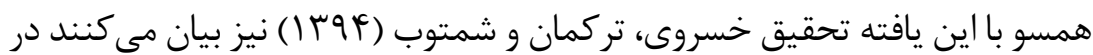
طراحى فضاها بايد ملاحظات زيبا و ساختارى در كنار خلق فضاهايى كه كودكان را قادر به توســـه يتانسيلهاى فكرى، خلاقانه، جسمى و روحى كند، مورد اهميت واقع گردد.

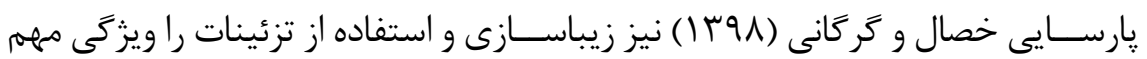
فضاهاى معمارى ايرانى اسلامى مى دانند. يكى ديخر از يافتهها در طراحى فضاى مدرسه توجه به جامعه ييرامونى بود. بدينصورت كه در بايد ارتباط نزديكى بين مدرسه و جامعه اطراف آن وجود داشته باشد. اگر مساجد و حســـينيهها، نزديك مدرسه باشند اثر بهترى بر شاخردان باقى مىنههند. جامعه اطراف 
مى تواند از فضاى نيايشى مدرسه استفاده كنند، مدرسه هم مىتواند از فضاى اطراف و يا

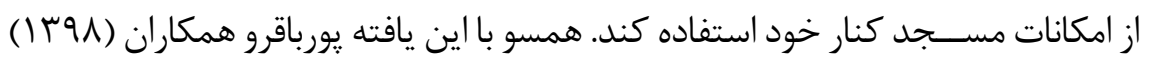

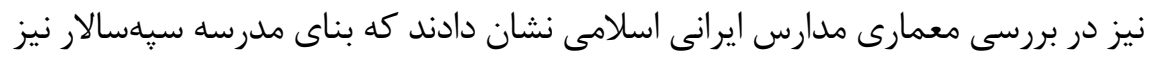
موقعيت مناسبى براى دسترسى مردم داشته است.

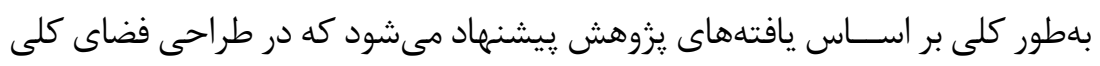
مدارس به موارد زير توجه شود:

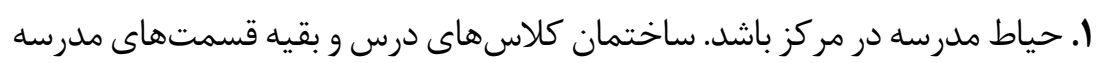

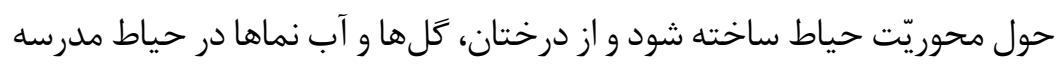

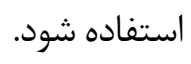
r. در طراحى كلاسها و راهروها به جذابيت و زيباسازى فضا توجه شود. براى تزيين

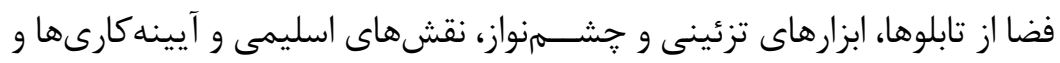

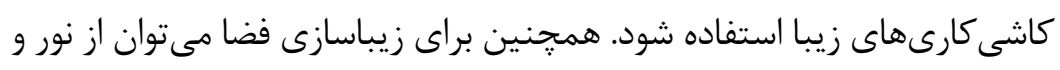
روشــنايى كه نمودى از طراحى مناسب در فضاى يادكيرى هست، استفاده نمود.

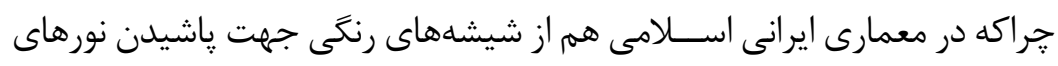

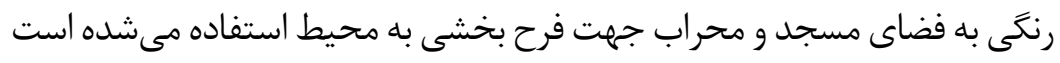

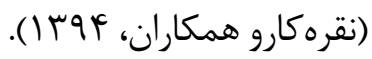

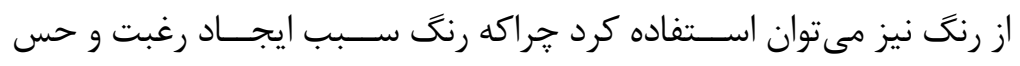

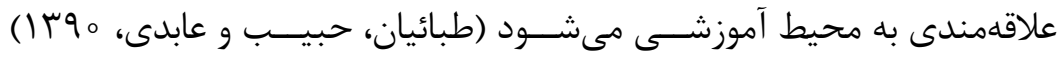

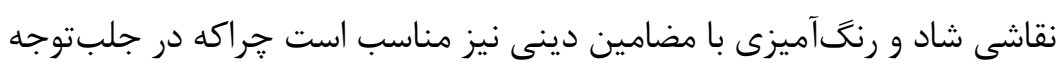

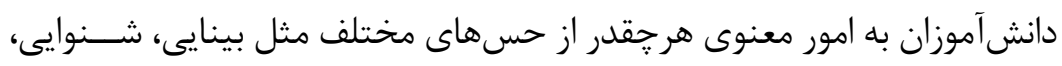
بويايى و... كمك بخيريم قطعاً موفقتر خواهيم بود.

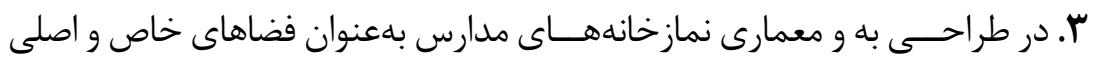

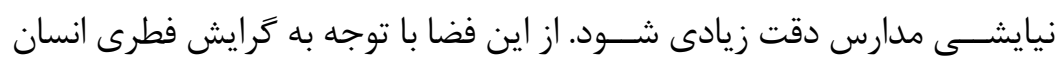

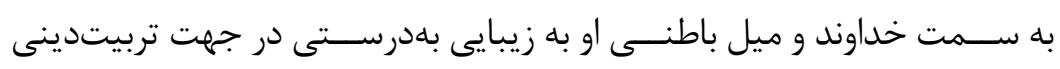

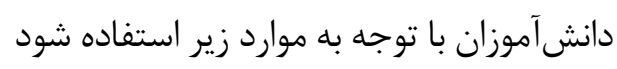

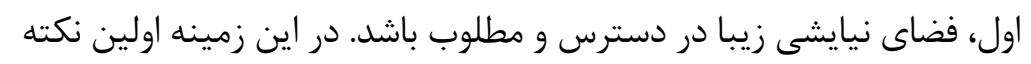

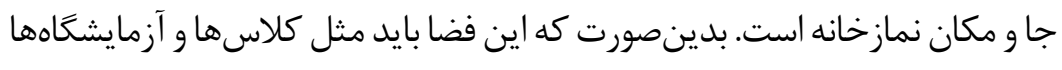


جزء فضاهاى اصلى و مهمم مدارس باشد و كاملاً براى همه دانشآموزان در دسترس باشـــد. بهطورى كه بهمحض ورود و يا حضور در مدرساءين فضا همانند نخينى در مدرسه بدرخشد و همه بخشهاى مدرسه كوتاهترين مسير را براى رسيدن به آن داشته باشند. به عبارتى بهجاى استفاده از مكانهاى جنبى مدرسه براى نمازخانه مكانهاى اصلى براى اين منظور در نظر زرفته شود.

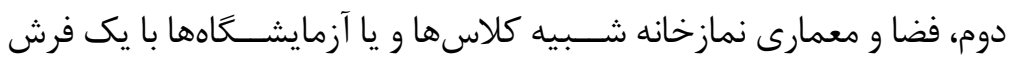
خالى نباشـــ. بلكه طراحى خاصى براى آن لحاظ شود. مثلاً محراب داشته باشد.

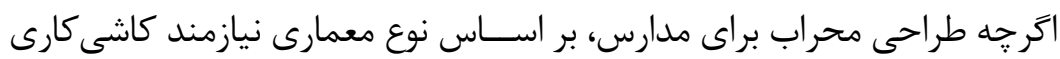
خاص و ير هزينه مىباشـــ، اما لحاظ كردن محراب در ساختار معمارى نمازخانه باعث الهامبخشى معنوى به دانش آموزان مىشود. جراكه محراب محل قرار گرفتن امام جماعت جايگاه اختصاصى وى هست و بهخودى خود ولايت يذيرى بين امام و مأموم را موجب معىشود.

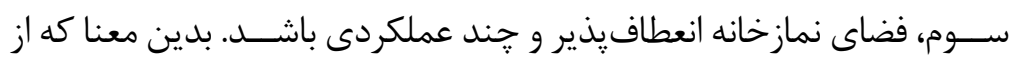

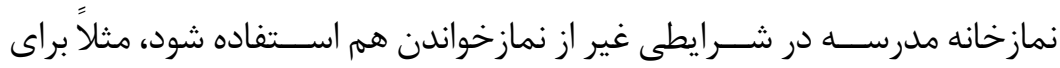
دورهمى هاى مدير و دانش آموزان يا مربيان و دانشآموزان. در واقع جند عملكردى كردن فضاهاى باز مدارس از حلقههاى مفقوده در فر آيند برنامهريزى مدارس كشور

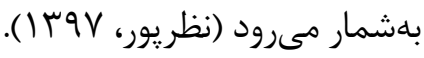

\section{تشكّر و قدردانى:}

از معاونت محترم يروهشى دانشگاه آزاد اسلامى واحد كازرون كه در انجام اين يروهش

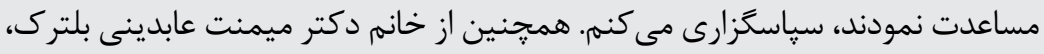
بهخاطر بازبينى متن مقاله و ارائه نظرهاى ساختارى مخصوصاً در تحليل دادههاى بخش مئش

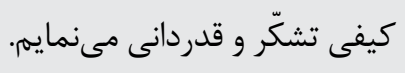




\section{منابع}

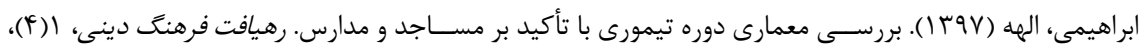
190-149

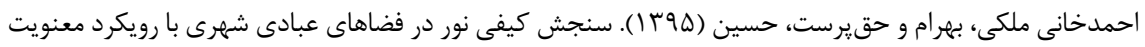

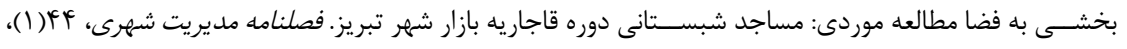
$109-91$

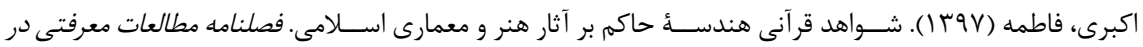
دانشEاه /سلامى،

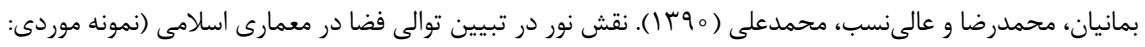

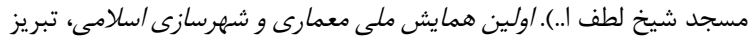

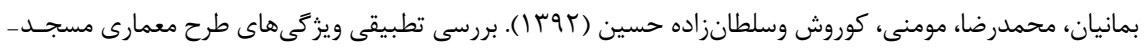

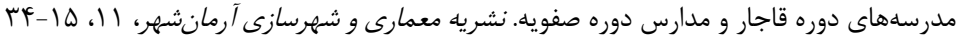

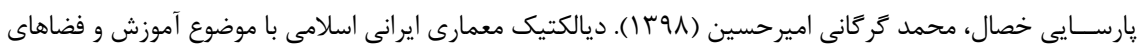

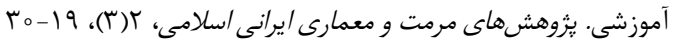

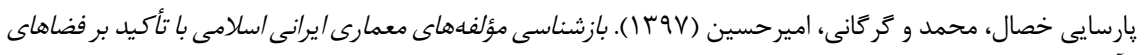

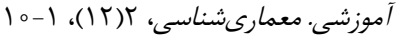

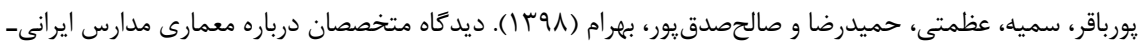

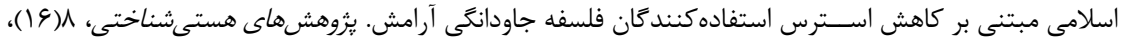

$\mid$ ITI IFF

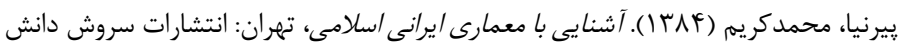

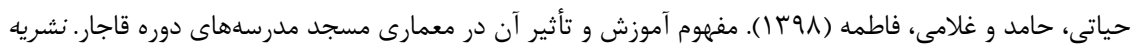

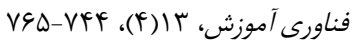

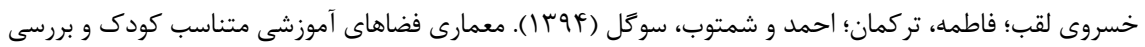

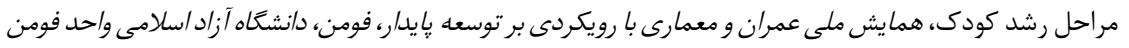

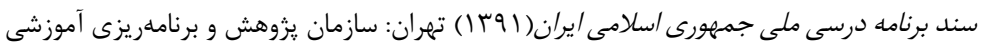

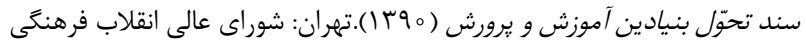

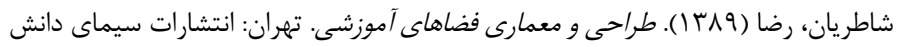

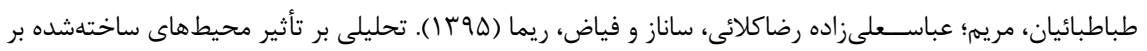

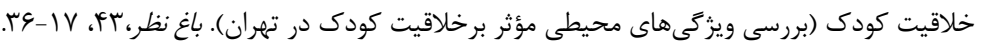

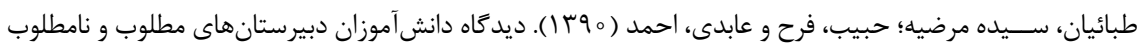

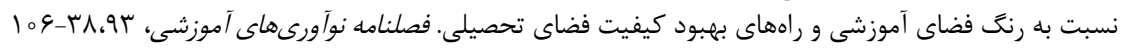

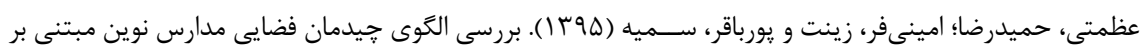

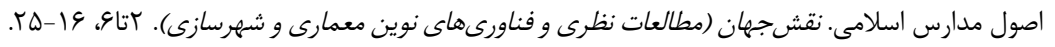

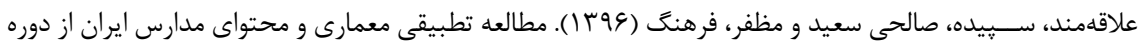
سنتى تا نوين. باغ نظر، و

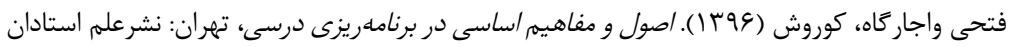

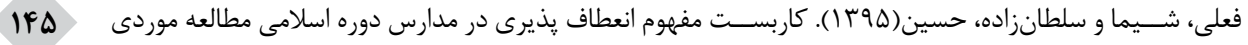

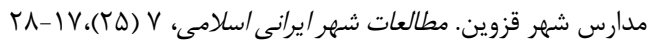

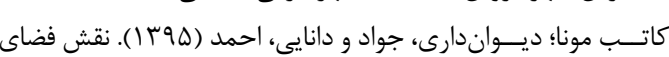

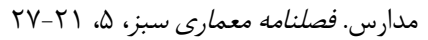

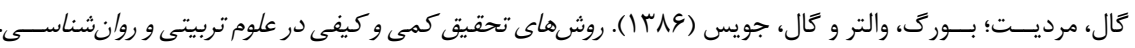




$$
\text { ترجمه احمدرضا نصر و ديخران. تهران: انتشارات سمت }
$$

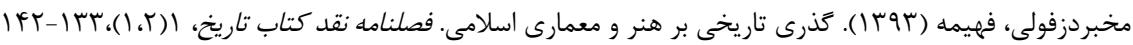

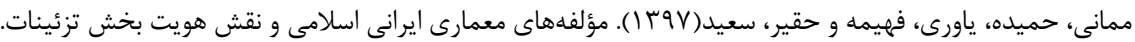

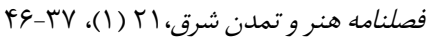

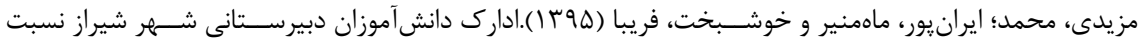

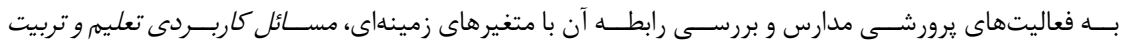

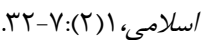

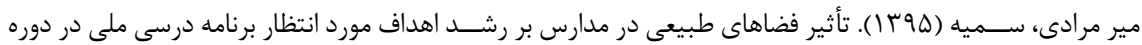

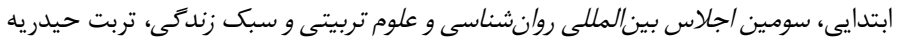

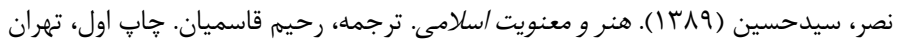

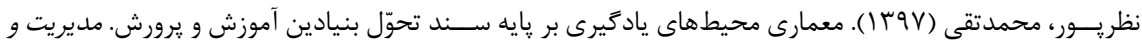

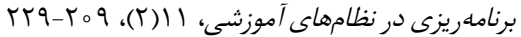

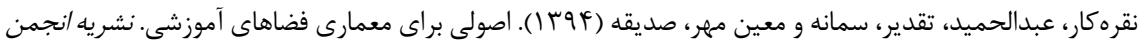

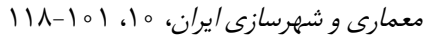

وثوقزاده، وحيده و حسنى يناه، محبوبه (1) (1)). حكمت آب و آيينه در معمارى اسلامى. مطالعات هنر و رسانه، (Y)، (Y)، $19 T-1 F r$

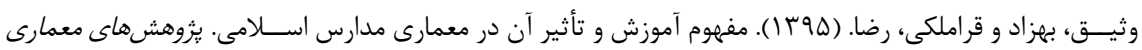

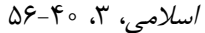

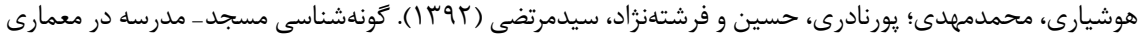

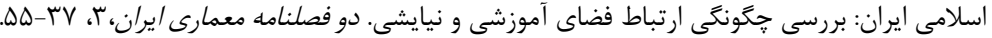

\section{REFERENCES}

Diekelmann, N., Allen, D., \& Tanner, C. (1989). The national league for nursing criteria for appraisal of baccalaureate programs: A critical hermeneutic analysis. New York: NLN Press

Hinds, J. \& Sparks, P. (2011). «The Effective Quality of Human-natural Environment Relationship». Journal of evolutionary psychology, 9(3): 451-469.

Godard, T. (2006). Learning Journeys; Isis Concepts limited; BCSE (Foundation for learning Environments) 